\title{
The Effect Of Learning Model Multimedia-Based Implementation Toward The Students' English Proficiency At Kolaka Regency
}

\author{
Kadaruddin, Karimuddin, IlhamTahir \\ Sembilanbelas November University, Kolaka \\ s.kadaruddin@yahoo.com, Wundulako 93561 Telp.08114006460 \\ Sembilanbelas November University, Kolaka \\ Sembilanbelas November University, Kolaka
}

\begin{abstract}
In an effort to help the students of the high school at Kolaka Regency improve their English proficiency, the researcher implements the learning model multimedia-based. The question of the research was "Is there any effect of the implementation of learning model multimedia-based toward the students' English proficiency at high schools of Kolaka Regency? The objective of the research was to solve the students' problem in learning English by creating an enjoyable learning model. The research was conducted at the high schools in Kolaka Regency. To investigate the effect of the implementation of the model, the researcher adopted Plomp's development method in Kadaruddin (2017) which consists of five steps; namely, (1) preliminary investigation, (2) planning, (3) realization/construction, (4) test, evaluation, and revision, and (5) implementation. Based on the results of the research, the mean score of pre-test was 33,8806 and the mean score of post-test was 69,4058 , while the t-table $18,55>2,042$ t-test. So, it can be concluded that the implementation of learning model multimedia-based has an effect toward the students' English proficiency. Based on the conclusion of the research, the researcher suggests to the teacher to presents the material in the activities that are more creative and innovative. One is through the use of learning model multimediabased. This has been done in order to provide a more interesting presentation of the material and relevant to the actual conditions and characteristics of the students. This research was funded by Direktorat Riset dan Pengabian Masyarakat (DRPM) Kementerian Riset, Teknologi dan Pendidikan Tinggi (Kemenristekdikti) Republik Indonesia.
\end{abstract}

Keyword - Learning Model Multimedia-Based

\section{INTRODUCTION}

Language is a tool of communication. It used by the people to convey their feeling, idea, expression, and many more. Without language, people can not understand what the other people want.
In the Indonesia education curriculum, there are four language skills that must be mastered. Such as; speaking, listening, reading, and writing. In addition to these four skills, also required mastery of language elements such as vocabulary, pronunciation, and grammar.

The problems in learning English are found. This can at least be attributed to five possible factors. First, English teachers still apply conventional methods, such as Grammar Translation Method in the classroom to teach students. Second, teachers and students are not able to use existing facilities and infrastructure. Third, teachers have not been professional or experienced enough to teach students. Therefore, students become demotivated and lose all their interest in learning in the classroom. Fourth, English is not the mother tongue. Fifth, the vocabulary and grammar of students is still very limited. Without adequate vocabulary and grammar, students will have difficulty in improving their English proficiency.

Based on the researcher experience, the learning in schools especially language subject is very effective if implemented through the innovations of learning models, such as learning model multimedia-based.

\section{LITERATURE REVIEW}

\section{A. Learning English Phenom in Indonesia}

In general, the condition of learning English in Indonesia is different from one region to another. Learning English in urban areas and tourist areas are easier than inland and not visited by many foreigners. The motivation to learn English in Indonesia is influenced by the extent to which English can be used in real life.In eastern Indonesia, there are still many undeveloped areas and tourist areas which visited by foreign tourists are still very limited. In these areas, the need for English has not been considered important. This is one of the obstacles to the lack of students' motivation to learn English. 
Based on the observations, it was found that the average proficiency of students in English in this area for example in Kolaka Regency is still low (Kadaruddin, 2016). One of the factors is the motivation to learn English are still low. This is an implication of the limited proficiency of teachers, learning methods that do not vary, and the use of learning multimedia is very limited.

To overcome these problems, an innovative and up-to-date learning model is required. The learning model in this case is the Learning Model Multimedia-based

\section{B. Learning Model}

The term 'Learning Model' consists of two words namely 'model' and 'learning'. The word 'model' as referred to From Wikipedia means the plan, representation, or description that describes an object, system, or concept, which is often simplification or idealization. The form can be a physical model (model, prototype), image model (design drawing, computer image), or mathematical formulation.

There are some definitions about the learning model such as stated by Istarani (2012) in the Indonesian Wikipedia, explained that the learning model is the whole set of presentation of teaching materials covering all aspects before, in learning process, and after learning which conducted by teachers and all related facilities that used directly or indirectly in the teaching and learning process.

While the word 'learning' according to MulyanaAina (2016) is a process of interaction between learners, between learners and educator, and between participants and other learning resources in an educational environment that took place educatively, so that learners can build attitudes, knowledge, and their skills to achieve the established goals.

Based on some definition above, it can be concluded that the learning model is a set of rules and guidelines that serve as a reference in the learning process from the planning stage, implementation phase, to the evaluation stage involving various supporting facilities to achieve the learning objectives.

\section{Learning Multimedia}

Kadaruddin (2016) states that multimedia is taken from two words that is 'multi' and 'media'. 'Multi' means a lot and 'media' means tools or intermediaries. Thus, multimedia can be defined as a combination of several media that can be used as a tool or an intermediary.

In a broader sense, multimedia can be defined as a combination of several elements of text, graphics, sound, video, and or animation that results in an interesting presentation. For multimedia computer users can be interpreted as computer information that can be exposed via audio or video, text, graphics, and animation.In addition, it can be described that multimedia is a combination of data or media to convey an information so that information presented with more interesting.

So, we can say that learning multimedia is a combination of several media, which is used as a means of delivering information in communication activities and interaction between teachers and students in the learning process.

\section{The Latest English Learning Model}

Learning English will be more successful if the learning is done by integrating one skill with another skill and involving language elements. For example, in conversation or dialogue learning, it should integrate the speaking and listening skills, as well as include explanations related to vocabulary, grammar, and pronunciation. Similarly, on other learning materials.

Learning English in Indonesia is not easy. Although the learning of English has begun from elementary school to university level, some even started from early age. One of the reasons for this is because English is not a mother tongue, so in learning English, students are often influenced by their mother tongue, both in terms of pronunciation, and the structure of the sentence. In addition, some students in some regions of Indonesia feel that the use of English has not been considered important (Kadaruddin, 2017).

\section{E. Learning Model Multimedia-Based}

Learning model multimedia-based is a model of learning that utilizes multimedia learning as the main means of presentation of learning materials. Multimedia learning that can be used in the form of interactive multimedia and linear multimedia by utilizing the use of computers, projectors (infocus), and sound system as the main device.The presentation can be individually, pairs, group, collaborative, and classical. While the learning materials can be general can also be contextual.

The main purpose of learning is to create a more live, fun, and less boring learning environment. With the atmosphere like this then the motivation of students in the learning process can be increased so that the learning objectives can be achieved optimally.

This learning model is an innovative learning model that requires the proficiency, creativity, and carefulness of teachers in choosing, creating, and using learning multimedia in accordance with the conditions and objectives of learning to be achieved.

\section{F. Preparation}

In order for this learning model multimedia-based to be properly applied, the following preparations are required:

1. inadequate multimedia and learning tools, electricity, and internet connection (if required), adequate and ready to use;

2. learning tools;

3. learning materials adapted to learning tools; and

4. guide the implementation of multimedia learning.

\section{G. Rare-step}

After the preparation stage has been well implemented, the steps of implementation of learning model multimedia-based of English as follows:

1. Explain to students about the learning objectives to be achieved;

2. Describe the learning scenario relating to the use of learning multimedia;

3. Present learning materials using pre-prepared learning multimedia; 
4. Provide an opportunity for students to pay attention to the presentation of the material through the use of multimedia learning;

5. Explain the learning materials that have been presented;

6. Observe all student activities during the learning process;

7. Repeating the required material presentation; and

8. Hold discussions and provide conclusions about the learning materials that have been presented.

\section{H. Variation}

Implementation of learning model multimedia-based English can be implemented individually, in pairs, groups, and classical, tailored to the learning objectives and multimedia learning used. This learning model can be implemented in the classroom or outside the classroom.

\section{METHOD OF THE RESEARCH}

\section{A. Design of the Research}

The design of the research was pre-experimental method with one group pre-test and post-test design. The design involves one group as pre-test $\left(0_{1}\right)$, expose to treatment $(\mathrm{x})$, and post-test $\left(0_{2}\right)$.

\section{TABLE1 Research design}

Where:

\begin{tabular}{l}
\hline$\left(0_{1}\right)$ \\
re-test \\
ost-test \\
$981: 225)$
\end{tabular}

\section{B. Variable}

The were two variables involve in this research to see the effects of learning model multimedia-based toward the students' English proficiency.

1) The use of learning model multimedia-based was categorized as the independent variable; and

2) The students' English proficiency was categorized as dependent variable.

\section{Population and Sample}

Population

The population of this research were all students of High Schools in Kolaka Regency. The total of school was 35.

\section{Sample}

The sample of this research were the students of first class of 11 junior high schools and first class of 11 senior high schools in Kolaka Regency. Regarding to sampling matter, the researcher used purposive sampling technique. While the sample of the research was taken from 1 school of junior high schools and 1 school of senior high schools each sub-Regency.

\section{Instrument of the Research}

In collecting the data, there was one kind of instrument utilized in this research. English test used to acquire detail information about the students' English proficiency after the teaching and learning process end.

\section{Procedure of Collecting Data}

In collecting data, there were procedures that the researcher has to do, they are:Pre-test, Treatment, and Post-test

\section{Technique of Data Analysis}

In this research, the researcher used descriptive inferential statistics to analyzing the data. Descriptive statistics used to describe the basic features of the data in the research and inferential statistics used to test the hypothesis. After gaining the data, the data was analysed by using SPSS (Statistic Product Service Solution).

\section{RESEARCH FINDINGS AND DISCUSSION}

\section{A. Findings}

The data where collected by administrating the test. The test was administrated twice namely pre-test and post-test. Pre-test was given before treatment and the post-test was given after treatment.

\section{Finding of analysis}

The analysis of the students finding to describe the students' result showed on the descriptive statistic. It was showed the different score of the students between the score of pre-test and post-test.

TABLE 2.The Students' Score in Pre-Test

\begin{tabular}{|l|l|l|c|c|c|}
\hline \multicolumn{5}{|c|}{ Descriptive Statistics } \\
\hline & $\mathrm{N}$ & Mean & $\begin{array}{c}\text { Std. } \\
\text { Deviation }\end{array}$ & Minimum & Maximum \\
\hline $\begin{array}{l}\text { Pre- } \\
\text { test }\end{array}$ & 31 & 33,8806 & 12,53980 & 21,21 & 76,11 \\
\hline
\end{tabular}

The table above showed that the result of the students in pre-test was the mean score was 33,8806, the standard deviation was 12,53980 , while the lowest score of the students was found 21,21 and the highest score of the students in pretest was 76,11

TABLE 3. The Students' Score Category in Pre-Test

\begin{tabular}{|c|ccc|l|c|c|}
\hline \multicolumn{7}{|c|}{ Pre-test } \\
\hline \multirow{2}{*}{ No } & \multicolumn{3}{|c|}{ Score } & Classification & \multicolumn{2}{c|}{ Students' Score } \\
\cline { 6 - 8 } & & - & 35 & Very poor & F & $\%$ \\
\hline 1 & 0 & - & 55 & Poor & 5 & $77,41 \%$ \\
\hline 2 & 36 & - & 65 & Fair & - & $0 \%$ \\
\hline 3 & 56 & - & 75 & Fairly good & - & $0 \%$ \\
\hline 4 & 66 & - & 85 & Good & 2 & $6,45 \%$ \\
\hline 5 & 76 & - & 95 & Very good & - & $0 \%$ \\
\hline 6 & 86 & - & - & - & $0 \%$ \\
\hline 7 & 96 & - & 100 & Excellent & 31 & $100 \%$ \\
\hline \multicolumn{7}{|c|}{ Total } \\
\hline
\end{tabular}


TABLE 4TheStudents' Score in Post-Test

\begin{tabular}{|c|c|c|c|c|c|}
\hline \multicolumn{5}{|c|}{ Descriptive Statistics } \\
\hline & $\mathrm{N}$ & Mean & $\begin{array}{c}\text { Std. } \\
\text { Deviation }\end{array}$ & Minimum & Maximum \\
\hline $\begin{array}{c}\text { Post- } \\
\text { test }\end{array}$ & 31 & 69,4058 & 12,47521 & 46,82 & 97,56 \\
\hline
\end{tabular}

The table above showed that the result of the students in posttest was the mean score was 69,4058 , the standard deviation was 12,47521 , while the lowest score of the students was found 46,82 and the highest score of the students in post-test was 97,56 .

TABLE 5TheSudents' Score Category in Post-Test

\begin{tabular}{|c|ccc|l|c|c|}
\hline \multicolumn{7}{|c|}{ Post-test } \\
\hline \multirow{2}{*}{ No } & \multicolumn{3}{|c|}{ Score } & Classification & \multicolumn{2}{c|}{ Students' Score } \\
\cline { 5 - 8 } & & & & $\mathrm{F}$ & $\%$ \\
\hline 1 & 0 & - & 35 & Very poor & 0 & $0 \%$ \\
\hline 2 & 36 & - & 55 & Poor & 5 & $16,13 \%$ \\
\hline 3 & 56 & - & 65 & Fair & 7 & $22,58 \%$ \\
\hline 4 & 66 & - & 75 & Fairly good & 10 & $32,26 \%$ \\
\hline 5 & 76 & - & 85 & Good & 5 & $16,13 \%$ \\
\hline 6 & 86 & - & 95 & Very good & 3 & $9,68 \%$ \\
\hline 7 & 96 & - & 100 & Excellent & 1 & $3,23 \%$ \\
\hline & \multicolumn{7}{|c}{ Total } & 31 & $100 \%$ \\
\hline
\end{tabular}

\section{Hypothesis Testing}

The t-test was formulated using SPSS program to found the effect of learning model multimedia-based. The t-test was success if t-table $>\mathrm{t}$-count. The hytpothesis testing or the t-test was showed on the table below:

TABLE 6The Paired Sample Test of $\mathrm{t}$-test

\begin{tabular}{|c|c|c|c|c|c|c|c|c|c|}
\hline \multicolumn{10}{|c|}{ Paired Sample Test } \\
\hline & & \multirow[t]{2}{*}{$\begin{array}{c}\mathrm{Me} \\
\text { an }\end{array}$} & \multirow[t]{2}{*}{$\begin{array}{c}\text { Std. } \\
\text { Deviati } \\
\text { on }\end{array}$} & \multirow{2}{*}{$\begin{array}{l}\text { Std. } \\
\text { Err } \\
\text { or } \\
\text { Me } \\
\text { an }\end{array}$} & \multicolumn{2}{|c|}{$\begin{array}{c}95 \% \\
\text { Confidence } \\
\text { Interval of } \\
\text { the } \\
\text { Difference }\end{array}$} & \multirow[t]{2}{*}{$\mathrm{t}$} & \multirow[t]{2}{*}{$\begin{array}{l}\mathrm{d} \\
\mathrm{f}\end{array}$} & \multirow[t]{2}{*}{$\begin{array}{l}\text { Sig. } \\
(2- \\
\text { taile } \\
\text { d) }\end{array}$} \\
\hline & & & & & $\begin{array}{c}\text { Low } \\
\text { er }\end{array}$ & $\begin{array}{c}\text { Upp } \\
\text { er }\end{array}$ & & & \\
\hline $\begin{array}{l}\mathrm{Pa} \\
\text { ir I }\end{array}$ & $\begin{array}{l}\text { Pre } \\
- \\
\text { test } \\
\text { Pos } \\
\text { t- } \\
\text { test }\end{array}$ & $\begin{array}{c}35 \\
53\end{array}$ & 10,67 & $\begin{array}{c}1,9 \\
2\end{array}$ & $\begin{array}{c}39,4 \\
4 \\
\end{array}$ & $\begin{array}{c}31,6 \\
1 \\
\end{array}$ & $\begin{array}{c}18 \\
55\end{array}$ & $\begin{array}{l}3 \\
0 \\
\end{array}$ & 0,00 \\
\hline
\end{tabular}

Based on the data above, the data value of t-test was bigger than the value of $t$-table. It indicates that there was a significant difference between the result of the students' English proficiency before and after treatment.

\section{B. Discussion}

The description of previous section shows the students' English proficiency has a significant. It was supported by the mean score of pre-test 33,8806 and post-test 69,4058. Based on the findings above, it can be concluded that there was a significant effect of learning model multimedia-based toward the students' English proficiency.

After calculating the score, the researcher found the students' English proficiency in hypothesis testing of the students in pre-test from the mean score 33,8806 on pre-test to be 69,4058 on post-test. It was supported by the mean score post-test of the students' English proficiency was higher than pre-test. Therefore, it can be said that the learning model multimedia-based can gave the effect toward the students' English proficiency. So, the $\mathrm{H}_{1}$ was accepted and $\mathrm{H}_{0}$ was rejected.

\section{V.CONCLUSION}

As has been stated before, the research was applied preexperimental design in High Schools in Kolaka Regency. Based on the finding and discussion, the researcher concludes as follows:

Learning Model Multimedia-based has an effect toward the students' English proficiency. It is proved by the meas score of the pre-test and post-test, which indicates the post-test value is higher than the pre-test while pre-test is 33,8806 and post-test is 69,4058 . Besided that, the result of statistical analysis at the level of significance is 0,05 which indicates ttest value is higher that t-table while $(18,55>2,042)$ with degrees of freedom (df) is 30 .

\section{REFERENCES}

[1] Istarani, (2012). Model PembelajaranInovatif. Medan: Media Persada

[2] Kadaruddin, (2016). InovasidanPemanfaatan Multimedia PembelajaranberbasisKomputerpada Program StudiPendidikanBahasaInggris. DP2M Dikti: Research Report.

[3] Kadaruddin, (2017). Use of Computer-Based Learning Multimedia at English Departement of UniversitasSembilanbelas November Kolaka.International Journal of Education \& Literacy Studies Volume: 5 Issue: 4 page $49-55$

[4] Mayer, R. E. (Ed.). (2005). The Cambridge handbook of multimedia learning.Cambridge University Press.

[5] MulyanaAina, (2016). [Online] Available: http://ainamulyana.blogspot.com/2016/04/model-pembelajaran-dalamkurikulum-2013.html (July 17, 2017)

[6] Rouse Margaret, [Online] Available: http://searchmicroservices.techtarget.com/definition/multimedia (August 8, 2017)

[7] ZainalAqib, (2014). Model-model, Media, danStrategiPembelajaranKontekstual (Inovatif). Bandung: YramaWidya 